\title{
Observed Performance and FEM-Based Parametric Analysis of a Top-Down Deep Excavation in Soil-Rock Composite Stratum
}

\author{
Gang Lei $\mathbb{D}^{1,2}$ Panpan Guo $\mathbb{D}^{1},{ }^{1}$ Fucai Hua, ${ }^{2}$ Xiaonan Gong, ${ }^{1}$ and Lina Luo ${ }^{3}$ \\ ${ }^{1}$ Research Center of Coastal and Urban Geotechnical Engineering, Zhejiang University, Hangzhou 310058, China \\ ${ }^{2}$ Beijing Urban Construction Design \& Development Group Company Limited, Beijing 100037, China \\ ${ }^{3}$ Guangzhou Railway Polytechnic, Guangzhou 510430, China \\ Correspondence should be addressed to Gang Lei; 11812105@zju.edu.cn and Panpan Guo; pp_guo@zju.edu.cn
}

Received 13 May 2021; Accepted 4 June 2021; Published 21 June 2021

Academic Editor: Yu Wang

Copyright ( 2021 Gang Lei et al. This is an open access article distributed under the Creative Commons Attribution License, which permits unrestricted use, distribution, and reproduction in any medium, provided the original work is properly cited.

This paper investigates the performance of a top-down deep excavation in soil-rock composite stratum. The behavior of the excavation bracing system, consisting of ground anchors and end-suspended piles, has not been well understood due to the lack of relevant research. Based on the observed data of a typical deep excavation case history for the May Fourth Square Station in Tsingtao, China, the characteristics of the horizontal and vertical pile displacements, ground surface settlements, building settlements, axial forces in ground anchors, earth pressure, and pore water pressure during excavation were analysed. Twodimensional finite element simulations were carried out to further explore the deformation and internal force responses of endsuspended piles and to capture the effects of pile diameter, embedded depth, and rock-socketed depth on the horizontal displacement and bending moment distributions along the pile shaft. It was found that the pattern of the vertical pile displacements could be categorized into three types: rapid settlement, slow settlement, and rapid heave. The magnitudes of the ground and building responses can be well controlled within allowable limits by combining the top-down method with the adopted bracing system. Among the investigated parameters, pile diameter is dominant in affecting the horizontal pile displacement. The primary influence zone for pile bending moment varies, depending on the parameters. It is recommended that a combination of top-down method, ground anchors, and end-suspended piles be adopted for restraining excavation deformation and lowering construction costs of similar deep excavations in soil-rock composite stratum.

\section{Introduction}

Excavations are generally made for constructing metros, mass rapid transit systems, high-rise buildings, underground oil tanks, and other facilities. With the rapid development of economy and urbanization, excavations are going deeper and becoming larger in scale. This highlights the significance of investigating the performance of deep excavations, especially for them that are under unsatisfactory geological conditions [1-4] or them that are in close proximity to constructed facilities or infrastructures [5-8].

In the past several decades, extensive studies have been conducted to investigate the performance of deep excavations in terms of excavation-induced deformation and internal force characteristics of retaining walls and bracing structures [9-11], ground movements [12-14], and response of preexisting structures that are adjacent to the excavations [15-17]. These studies are based mainly on numerical simulations [18, 19], empirical or semiempirical methods $[20,21]$, analytical solutions [22, 23], in situ monitoring data analysis $[24,25]$, centrifuge or scaled model testing $[26,27]$, and machine learning $[28,29]$. Among the commonly adopted methods, numerical simulations usually predict better results for excavation-induced wall displacements than for ground movements and can consider the effects of excavation stages and nonlinearity of soil behavior [30,31]. In addition, as the design of the bracing system for a deep excavation is still heavily dependent on semiempirical and empirical methods $[32,33]$, an update on the well-documented deep excavation case histories by in situ monitoring data analysis will be 


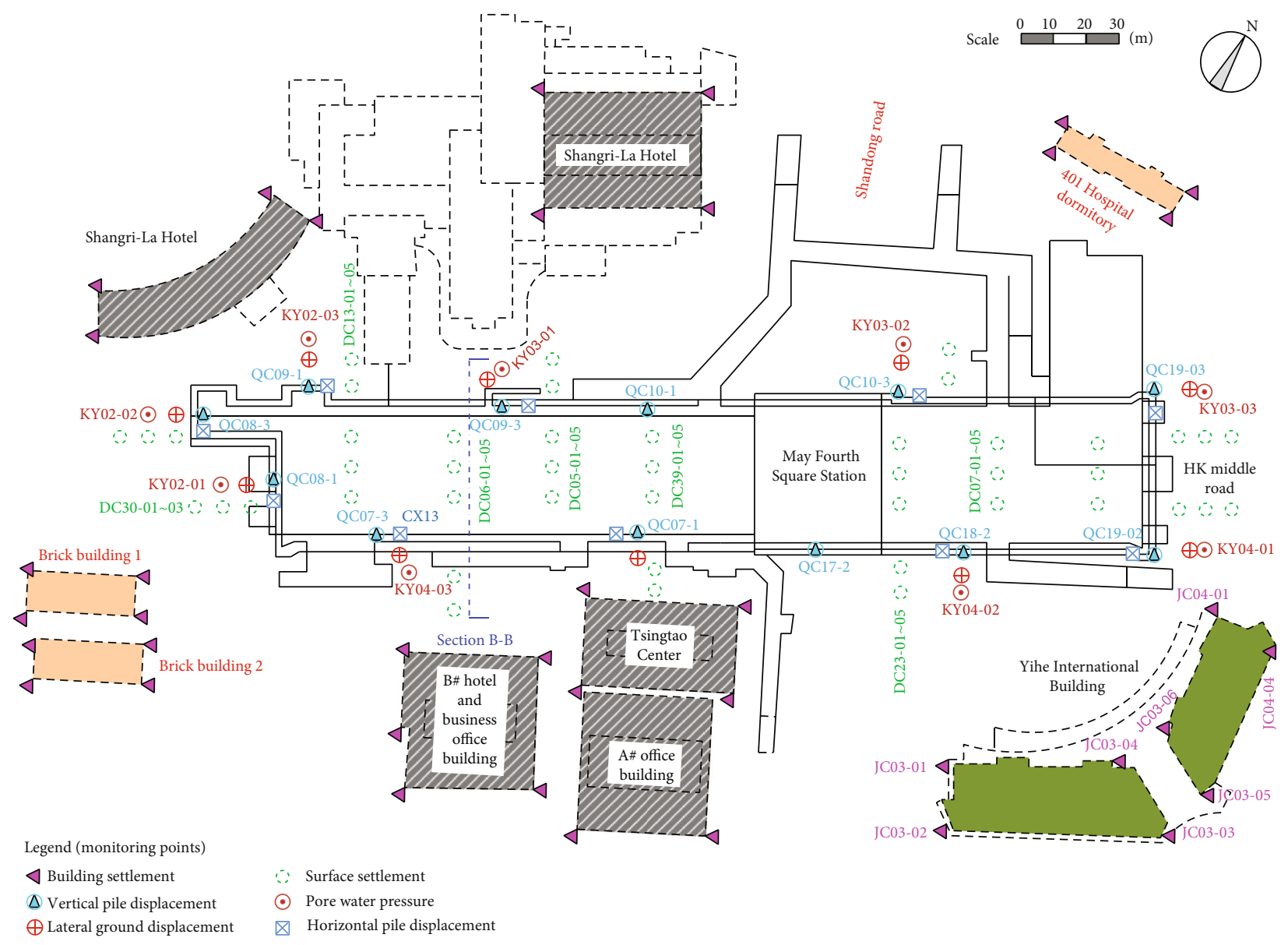

Figure 1: Plan view of the May Fourth Square Station excavation case history.

beneficial for relevant researchers, designers, and engineers by providing timely feedback helpful for lowering the risk for construction and design.

The performance of deep excavations varies according to excavation geometry and scale, geological conditions, excavation method, type of retaining structure, and other factors. Tan et al. [34] found that for a long and narrow deep excavation, the minimum wall deflections occurred near the excavation corners while the maximum near the middle span of the excavation. This can be attributed to the corner strengthening effect which has also been investigated by Lee et al. [35] and $\mathrm{Ou}$ and Shiau [36]. The geological conditions significantly affect the design of the excavation bracing system and thus the construction duration and cost. A great deal of efforts were made to understand the performance of deep excavations in various types of soils including soft clays [37], sand [38], granite [39], sand covered karst [40], and loess [41].

The commonly adopted excavation methods mainly include the bottom-up method, the top-down method, and the semitop-down method. Due to its advantages of short excavation duration, low construction cost, and easy operation, the bottom-up method was used for constructing many metrostations or basements in soft soils $[42,43]$. To avoid the risk of excessive ground movements and tremendous distur- bance to the existing structures or facilities involved in the bottom-up method, the top-down method is frequently adopted in deep excavations in congested urban environment [44-46]. Recently, an innovative excavation method termed semitop-down method, which is superior to the abovementioned two methods, has been used in several excavations in downtown Shanghai [47]. In addition, as for the type of retaining structure for a deep excavation, flexible retaining systems (e.g., soldier pile walls and sheet pile walls) and stiff diaphragm walls are prevalent and have been extensively investigated. Some observed data has proved that the empirical or semiempirical prediction methods based on flexible retaining systems may overestimate the ground movements and wall deflections corresponding to stiff diaphragm walls [48-51]. Despite the plenty of studies on the performance of deep excavations, the performance of deep excavations braced with ground anchors and end-suspended piles in soil-rock composite stratum has not been well understood.

The end-suspended piles have been successfully applied for supporting deep excavations in the soil-rock composite stratum in many cities in China such as Tsingtao, Guangzhou, Shenzhen, and Wuhan where the bedrock is relatively shallowly buried. Due to the difficulty of constructing castin-place pile in hard rock stratum and the limitation of 


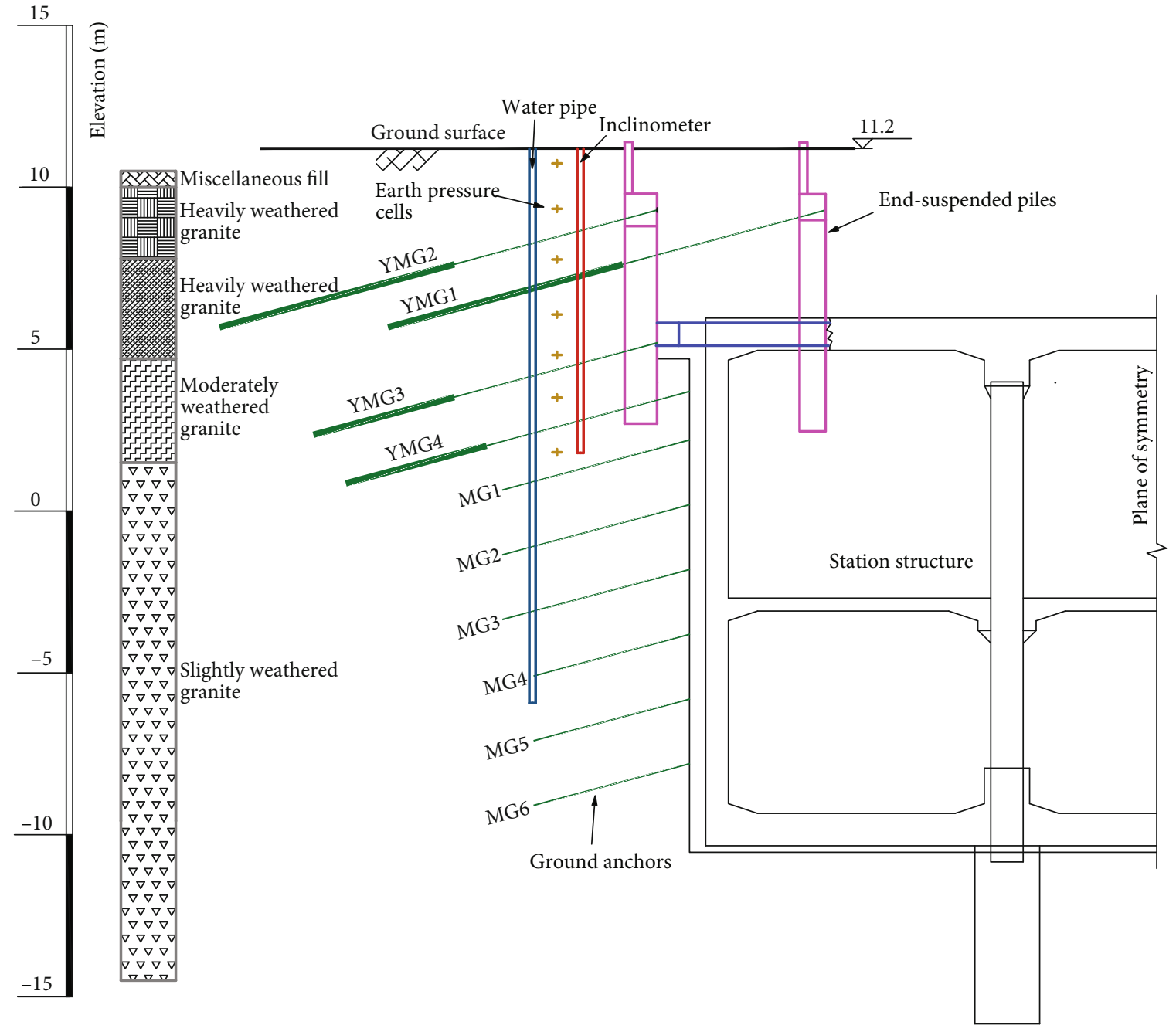

Figure 2: Profile of Section B-B.
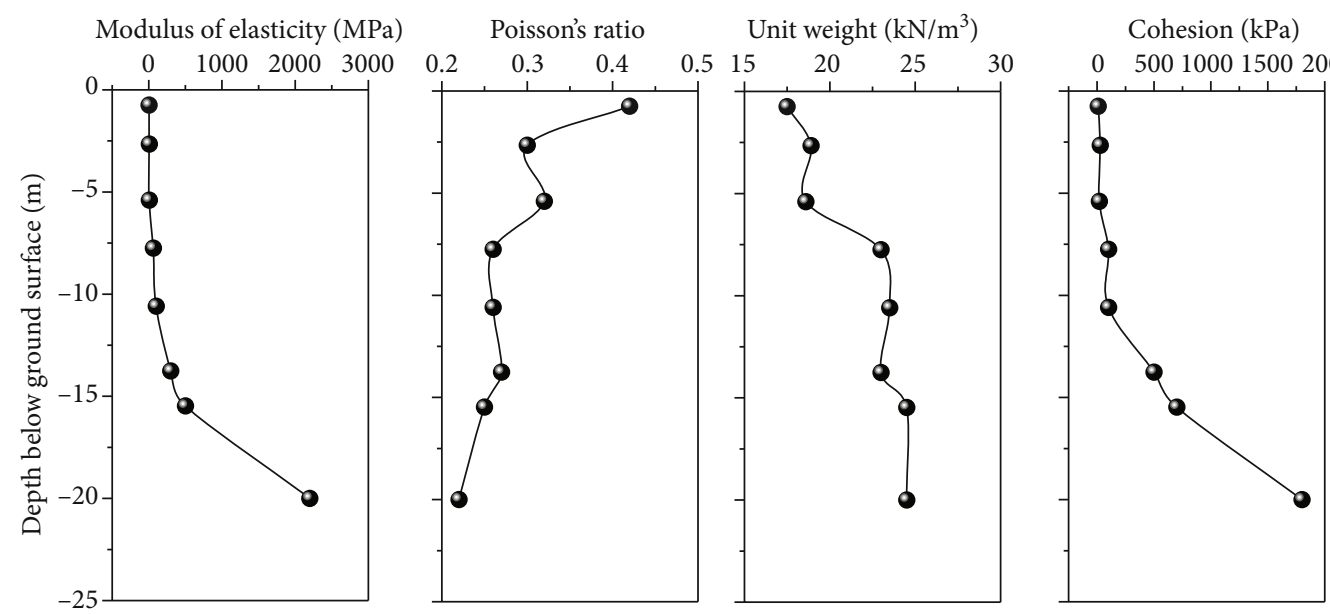

Angle of internal friction $\left(^{\circ}\right.$



Figure 3: Variations of soil parameters with depth below ground surface.

project budget, the bottom of end-suspended pile in this case is above the final excavation bottom. This feature differentiates the deep excavation braced with end-suspended piles from that braced with conventional piles. In order to further expedite the application of end-suspended piles in deep excavations and optimize their design, a deeper understanding of 
TABLE 1: Summary of the main construction activities.

\begin{tabular}{|c|c|c|}
\hline Stage & Construction activities & Duration (days) \\
\hline 1 & Excavate to top slab, construct columns and top slab, and backfill and restore traffic & 78 \\
\hline 2 & Construct end-suspended piles, excavate to $2 \mathrm{~m}$ BGS & 59 \\
\hline 3 & Install ground anchors YMG1 and YMG2, apply prestress of $200 \mathrm{kN}$ & 17 \\
\hline 4 & Excavate to $5 \mathrm{~m}$ BGS & 14 \\
\hline 5 & Construct temporary support & 9 \\
\hline 6 & Excavate to $7 \mathrm{~m}$ BGS & 12 \\
\hline 7 & Install ground anchors YMG3, apply prestress of $100 \mathrm{kN}$ & 19 \\
\hline 8 & Excavate to $8 \mathrm{~m}$ BGS & 22 \\
\hline 9 & Install ground anchors YMG4, apply prestress of $310 \mathrm{kN}$ & 16 \\
\hline 10 & Excavate to $9.5 \mathrm{~m}$ BGS & 13 \\
\hline 11 & Install ground anchors MG1 & 7 \\
\hline 12 & Excavate to $12 \mathrm{~m}$ BGS & 15 \\
\hline 13 & Install ground anchors MG2 & 23 \\
\hline 14 & Excavate to $13.5 \mathrm{~m} \mathrm{BGS}$, cast middle slab & 17 \\
\hline 15 & Install ground anchors MG3 & 26 \\
\hline 16 & Excavate to $15.5 \mathrm{~m}$ BGS & 11 \\
\hline 17 & Install ground anchors MG4 & 18 \\
\hline 18 & Excavate to $17.5 \mathrm{~m}$ BGS & 29 \\
\hline 19 & Install ground anchors MG5 & 21 \\
\hline 20 & Excavate to $20 \mathrm{~m}$ BGS & 10 \\
\hline 21 & Cast base slab & 19 \\
\hline
\end{tabular}

the performance of deep excavations braced with endsuspended piles and the effects of many important parameters is necessary. In addition, the soil-rock composite stratum is characterized by soft soil in the upper position and hard rock in the lower position. Because of this, blasting excavation may be required and careful design of the excavation bracing system is necessary for reducing the construction cost and ensuring safety and stability.

In this paper, a case history of top-down deep excavation braced with ground anchors and end-suspended piles in the soil-rock composite stratum was reported. The observed performance of the deep excavation in terms of horizontal and vertical pile displacements, ground surface settlements, building settlements, axial forces in ground anchors, earth pressure, and pore water pressure was analysed. Moreover, a parametric study based on two-dimensional (2D) finite element method was conducted to capture the effects of pile diameter, embedded depth, and rock-shoulder width on the deformation and internal force characteristics of end-suspended pile.

\section{Case History Description}

2.1. Engineering Background. Figure 1 shows a plan view of the considered deep excavation case history. The May Fourth Square (MFS) Station, serving as an interchange station for Lines M2 and M3 of Tsingtao Metro Line 3, is located at the intersection of the HK Road and the Shandong Road. The MFS Station, consisting of 5 passageways and 2 firefighting entrances, has a length of $277.8 \mathrm{~m}$ and a width of

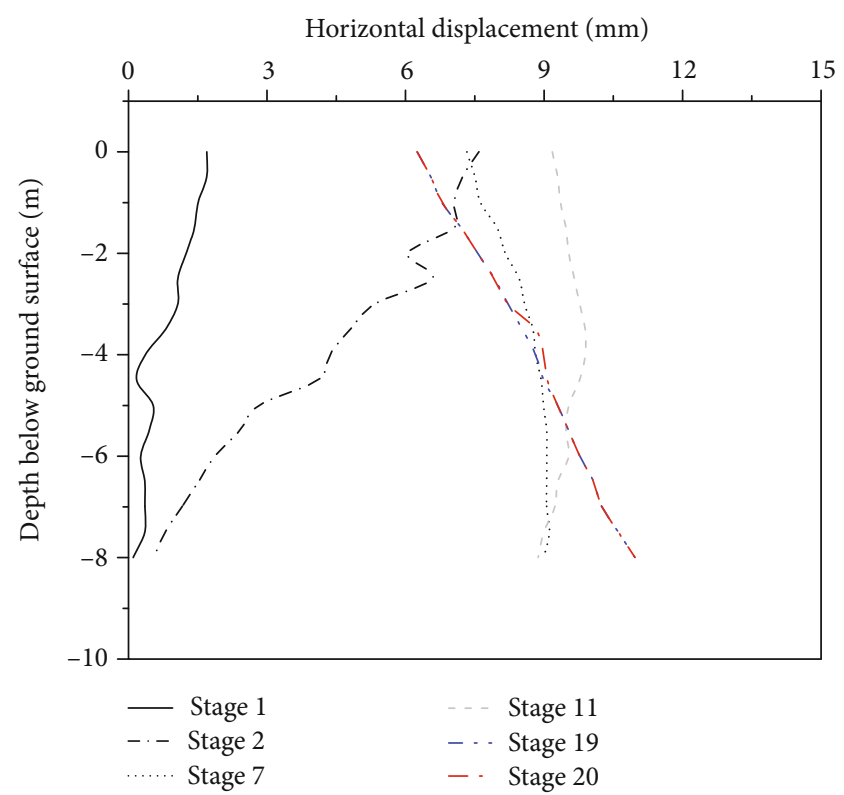

FIgUre 4: Horizontal displacements of end-suspended pile CX13 at various construction stages.

$44.8 \mathrm{~m}$. The cover depth of the Station ranges between 3.7 and $6.9 \mathrm{~m}$. The $20 \mathrm{~m}$ deep excavation was bounded by the 401 Hospital dormitory to the north, by the Tsingtao Center and its hotel and office buildings to the south, by 2 brick buildings and the Shangri-La Hotel (15-19 stories) to the west, and by the Yihe International Building to the east. 


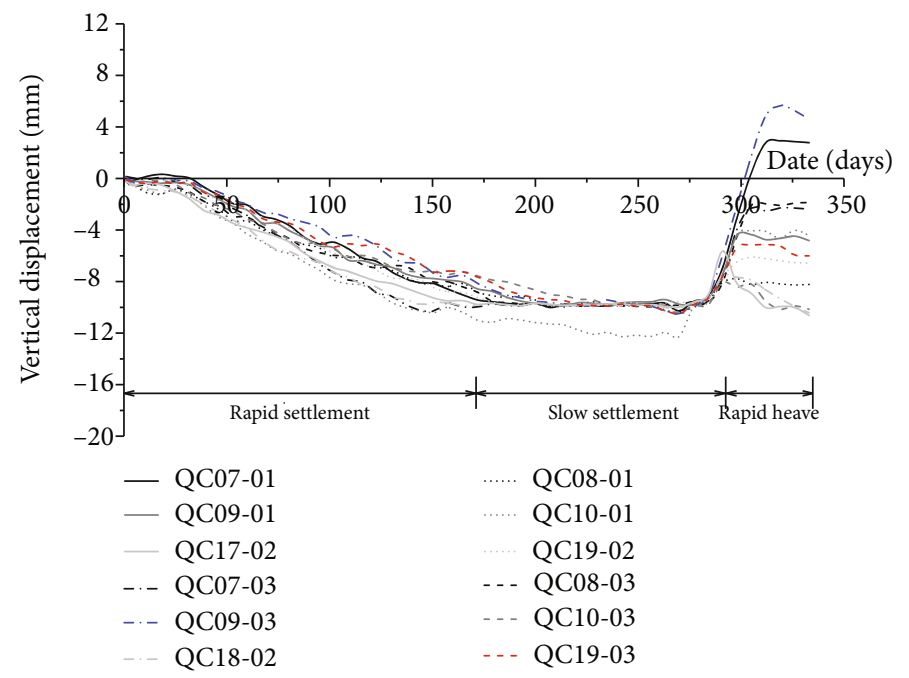

Figure 5: Time histories of vertical displacements of the end-suspended piles.

Figure 2 shows a profile of Section B-B as illustrated in Figure 1. The excavation, made using the top-down method, was braced with end-suspended piles and both prestressed ground anchors (i.e., YMG1, YMG2, and YMG3) and general ground anchors (i.e., MG1-MG6). The vertical and horizontal spacings between two ground anchors were, respectively, 1.9 and $1.8 \mathrm{~m}$. The borehole diameter and the inclination angle with respect to the horizontal direction for a ground anchor were, respectively, $0.15 \mathrm{~m}$ and $15^{\circ}$. The diameter of the end-suspended piles was $0.8 \mathrm{~m}$ on the inner side row and $1.0 \mathrm{~m}$ on the outside row. The length of the endsuspended piles ranged between 6.5 and $8.0 \mathrm{~m}$.

The subsurface conditions at the site consist of a miscellaneous fill (MF) layer of $2 \mathrm{~m}$ in thickness overlying a sequence of granite layers. The granite layers, in descending order, are heavily weathered granite (HWG) layer, moderately weathered granite (MWG) layer, and slightly weathered granite (SWG) layer. The groundwater mainly consists of pore water and bedrock fissure water which is near to the structural belt. A detailed geotechnical investigation including in situ and laboratory tests was performed to determine the soil parameters for this case history. The variations of several important parameters, which are modulus of elasticity, Poisson's ratio, unit weight, cohesion, and angle of internal friction, with depth below ground surface, are plotted in Figure 3. Evidently, the modulus of elasticity, cohesion, and angle of internal friction for the SWG and MWG layers are significantly greater than that for the HWG and MF layers.

2.2. Field Instrumentation. A plan view of the field instrumentation layout is presented in Figure 1. Figure 2 gives a profile of the instrumentation. The instrumented items included horizontal and vertical pile displacements, ground surface settlements, building settlements, axial forces in ground anchors, earth pressure, and pore water pressure. The horizontal and vertical pile displacements were monitored using inclinometers. Level instruments were used to monitor the ground surface settlements and building settle- ments with a minimum spacing of $2.0 \mathrm{~m}$. The monitoring points for building settlements were created by drilling on the building corners using percussion drilling and then installing L-shaped iron nails. The axial forces in ground anchors were monitored using steel stress meters welded to the main reinforcement of the ground anchors. The earth pressure was monitored using the earth pressure cells, which were installed on the outside of the end-suspended piles. The elevations of the earth pressure cells corresponded to that of the steel stress meters. Monitoring of pore water pressure was automatically performed throughout the excavation stages using the vibrating-wire piezometer cells located in the water pipe boreholes close to the inclinometers. All instrumentation was installed and calibrated at least two weeks before the beginning of any construction work at the site. Accuracy of the observed data was periodically checked during the excavation.

2.3. Construction Stages. Table 1 summarizes the main construction activities as well as their duration at the site. Work began with the excavation of the soil above the top slab. After this, the columns and the top slab with a thickness of $1 \mathrm{~m}$ were constructed. The concrete filled steel tubular columns were of $0.8 \mathrm{~m}$ in external diameter, $0.02 \mathrm{~m}$ in wall thickness, and $7.8 \mathrm{~m}$ in spacing. When the top slab was completed, backfilling of the excavated miscellaneous fill and construction of the pavement were conducted to restore the traffic. Excavation then proceeded as described in Table 1. The inner side row of the end-suspended piles extended to a depth of $8.5 \mathrm{~m}$ below ground surface, whereas the outside row penetrated to a depth of $15 \mathrm{~m}$ below ground surface. As the construction activities proceeded, 8 levels of ground anchors were installed to brace the end-suspended piles and the excavation. Ground anchors at the first level consisted of YMG1 and YMG2, and they were preloaded with approximately $60 \%$ of the design ground anchor load. The second and third levels of ground anchors were preloaded, respectively, with a load of 100 and $310 \mathrm{kN}$. 


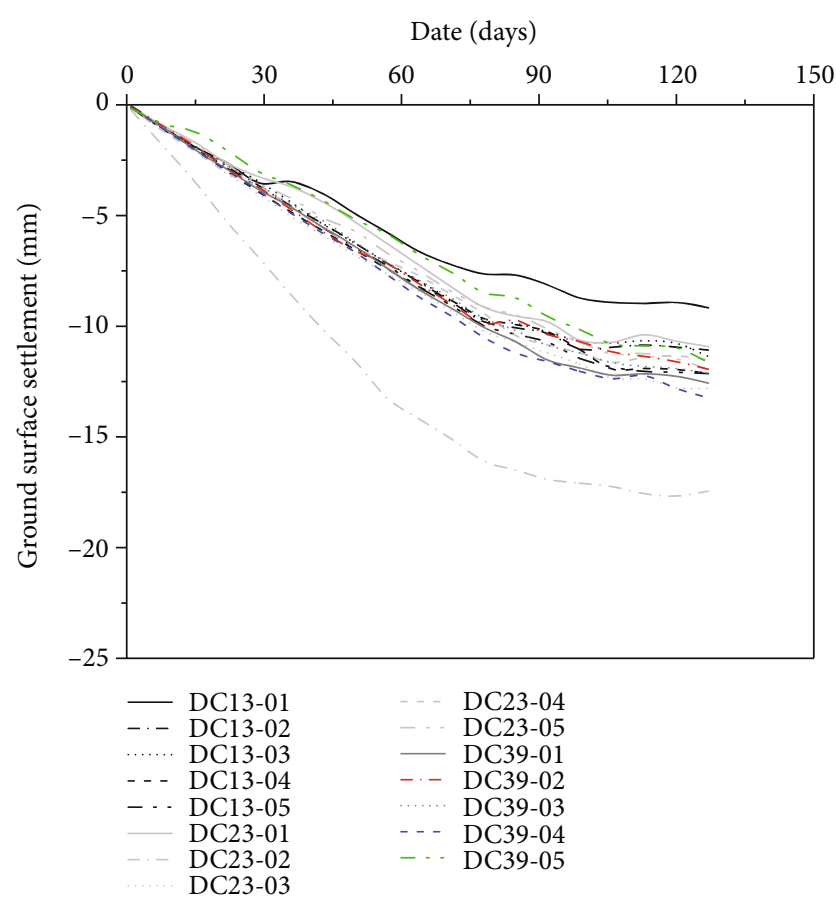

FIGURE 6: Time histories of ground surface settlements along lines of DC13, DC23, and DC39.

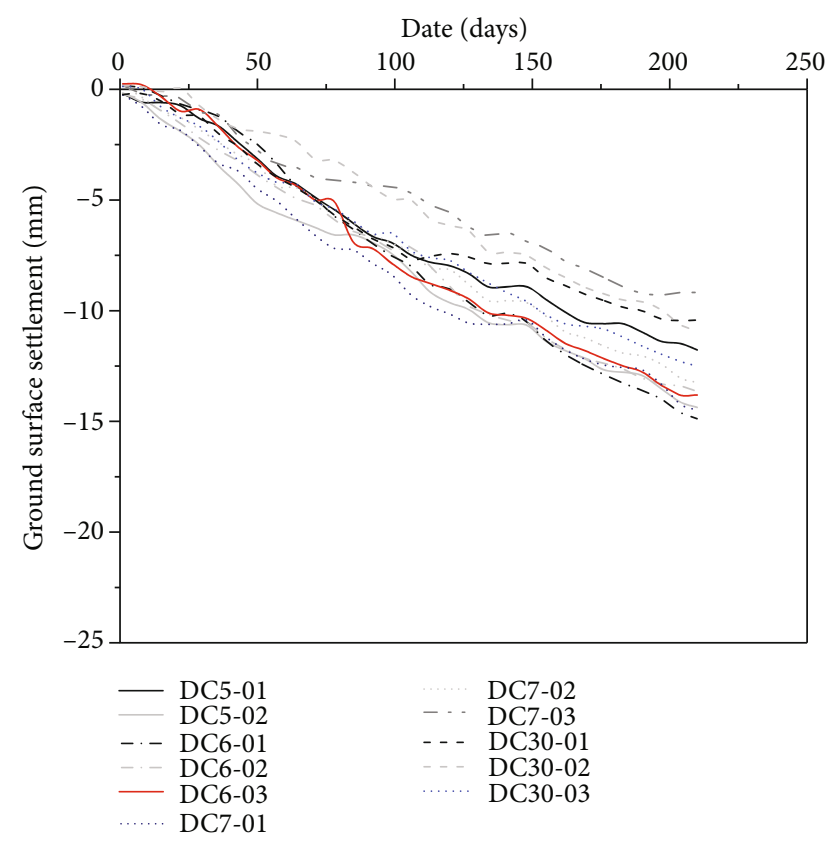

FIGURE 7: Time histories of ground surface settlements along lines of DC05, DC06, DC07, and DC30.

\section{Observed Performance during Excavation}

3.1. Horizontal and Vertical Pile Displacements. The magnitude of the horizontal displacements of the end-suspended piles affects not only the stability of the pile but also the ground movements surrounding the excavation. Figure 4 presents the subsurface distributions of horizontal pile dis-

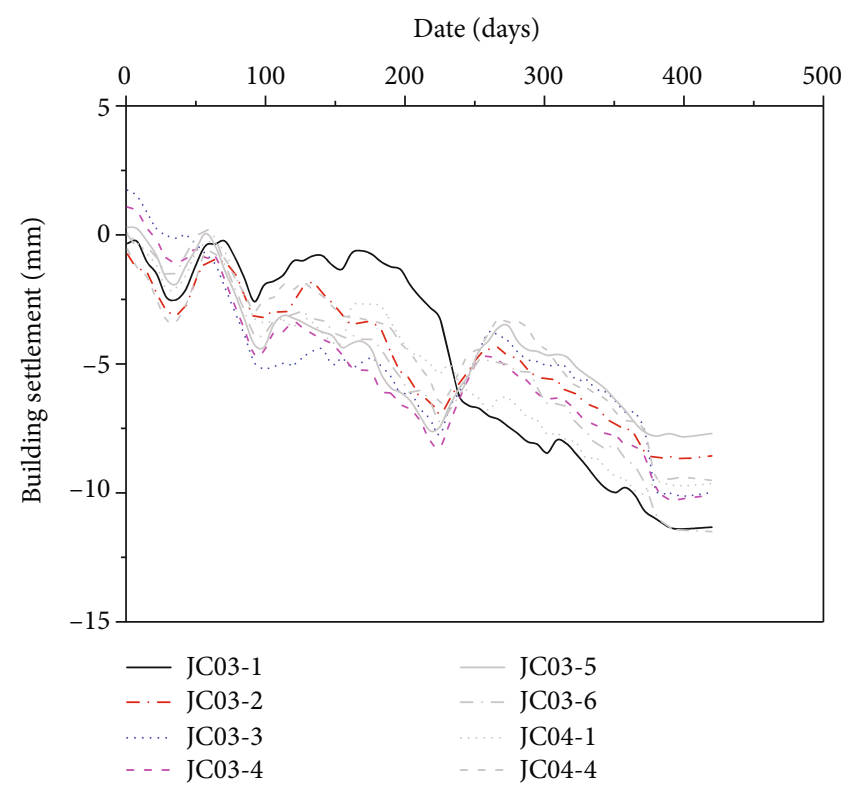

FIgURE 8: Time histories of settlements of the Yihe International Building.

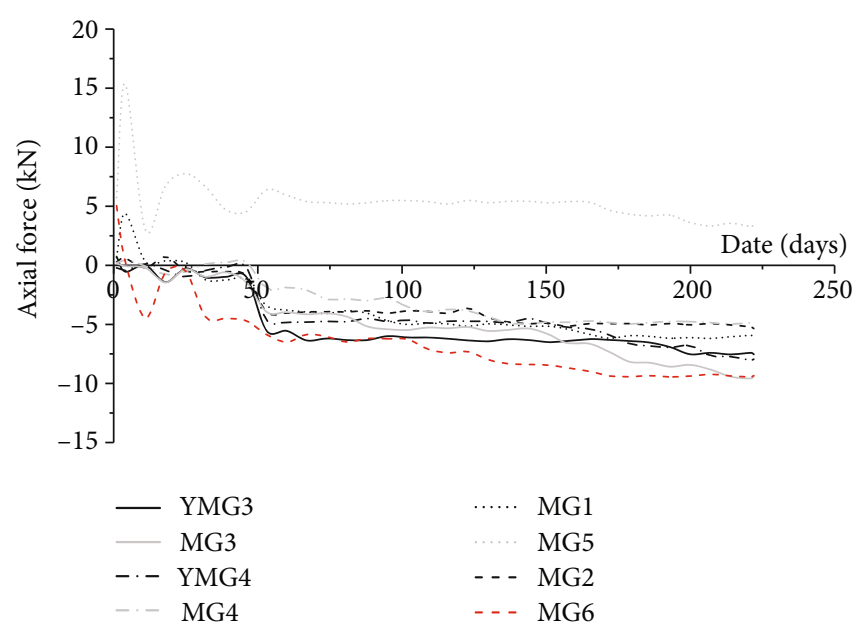

FIgURE 9: Time histories of axial forces in ground anchors.

placements at CX13 for several construction stages as detailed in Table 1. It can be indicated that when the excavation proceeded to $2 \mathrm{~m}$ below ground surface, the horizontal pile displacement was trivial with its maximum being less than $3 \mathrm{~mm}$. This could likely be attributed to the fact that the excavation depth was small and the excavation exposure duration was short. As the excavation depth increased, the horizontal pile displacements throughout the entire pile length significantly increased. The maximum horizontal pile displacement occurred initially at the pile top at the first two excavation stages. After the excavation stage proceeding to 7 , the maximum horizontal pile displacement occurred at the pile tip. Although the embedded depth of the end-suspended piles into the MWG layer was only $2 \mathrm{~m}$, the restraining effect of the embedded section was sufficient to ensure the stability of the end-suspended pile during excavation. 


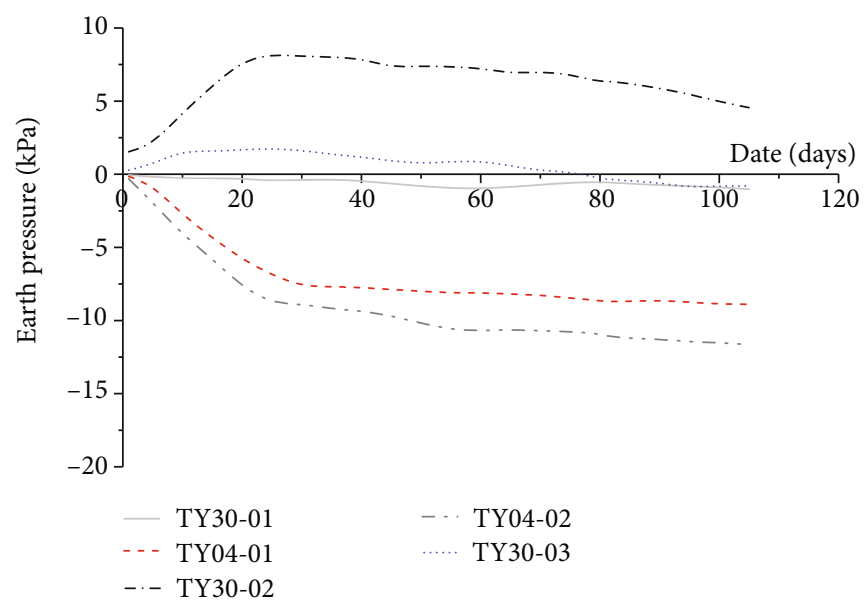

FIGURE 10: Time histories of earth pressure at various monitoring points.

Figure 5 shows the time histories of the vertical displacements atop the end-suspended piles. It can be found that the pattern of the vertical pile displacements could be categorized into three types: rapid settlement, slow settlement, and rapid heave. The rapid settlement pattern occurred before the backfilling of the excavated MF layer above the top slab. Throughout the pattern of slow settlement, the maximum vertical pile displacement of $-12.28 \mathrm{~m}$ in magnitude was achieved. When the excavation depth proceeded to be greater than $15.5 \mathrm{~m}$, the pattern of rapid heave appeared due to the pronounced stress relaxation effect caused by excavation. The maximum heave of the end-suspended piles was $5.68 \mathrm{~mm}$.

3.2. Ground Surface Settlements. Figure 6 shows the time histories of the ground surface settlements along monitoring lines of DC13, DC23, and DC39. It can be indicated that the rate and the magnitude of the ground surface settlement was much greater at DC23-02 than at other surface settlement monitoring points. Before July 19, 2012, the daily surface settlement was approximately $-0.4 \mathrm{~mm}$, and this value decreased to be -0.1 to $-0.2 \mathrm{~mm}$ as time went on. Up to August 31, 2012, the maximum surface settlement was reached with a magnitude of $-17.68 \mathrm{~mm}$. In addition, neither the daily surface settlement nor the accumulated surface settlement exceeded the design value and the alarm value.

Figure 7 shows the time histories of the ground surface settlements along monitoring lines of DC05, DC06, DC07, and DC30. It can be noticed that the ground surface settlements were continuous during the excavation with the daily surface settlement being about $-0.2 \mathrm{~mm}$. The rapid settlement phase was replaced by the slow settlement phase after the achievement of the final excavation depth. The maximum surface settlement was $-14.88 \mathrm{~mm}$, which was also less than the design and the alarm values. The relatively small ground surface settlement induced by a top-down deep excavation benefited from the bracing effect of the top slab. Therefore, in soil-rock composite stratum, the top-down method is preferable to the bottom-up excavation method.
3.3. Building Settlements. To analyse the excavation induced building settlements, the Yihe International Building, which was, respectively, 24 and $63 \mathrm{~m}$ apart from the $4 \#$ and the $3 \#$ passageways, was selected as the representative. Figure 8 shows the time histories of the Yihe International Building settlements. It is noted that the building settlements occurred at the 8 monitoring points increased in a wave-shaped manner with proceeding the construction date. Several rebounding trends on the time history curves are observable. This phenomenon may be attributed to the preloading of the ground anchors. Among the considered monitoring points, the JC04-1, nearest to the excavation, settled most, with the maximum settlement being $-10.71 \mathrm{~mm}$.

3.4. Axial Forces in Ground Anchors. Figure 9 shows the time histories of the axial forces in ground anchors. It can be recognized that the variation of the axial forces in ground anchors was rather complex in the early stage of the excavation. After the backfilling of the soil above the top slab, the axial force in ground anchor MG5 decreased gradually. In the meantime, the axial forces in ground anchors YMG3, MG4, and MG2 remained almost unchanged, while the axial forces in ground anchors YMG4, MG1, MG3, and MG6 increased slightly. For the investigated case history, a combination of ground anchors and end-suspended piles has provided satisfactory bracing effect.

3.5. Earth Pressure. Figure 10 shows the time histories of the earth pressure at monitoring points TY03-01, TY03-02, TY03-03, TY04-01, and TY04-02. It is shown that the earth pressure at TY03-02 and TY03-03 increased before the $25^{\text {th }}$ construction days and then decreased with proceeding the construction days. However, unlike the variational characteristics of earth pressure at TY03-02 and TY03-03, the earth pressure at TY03-01, TY04-01, and TY04-02 consistently decreased with proceeding the construction days. The decreasing trend of the earth pressure could be attributed to the increase in the horizontal displacements of the ground surrounding the excavation. 


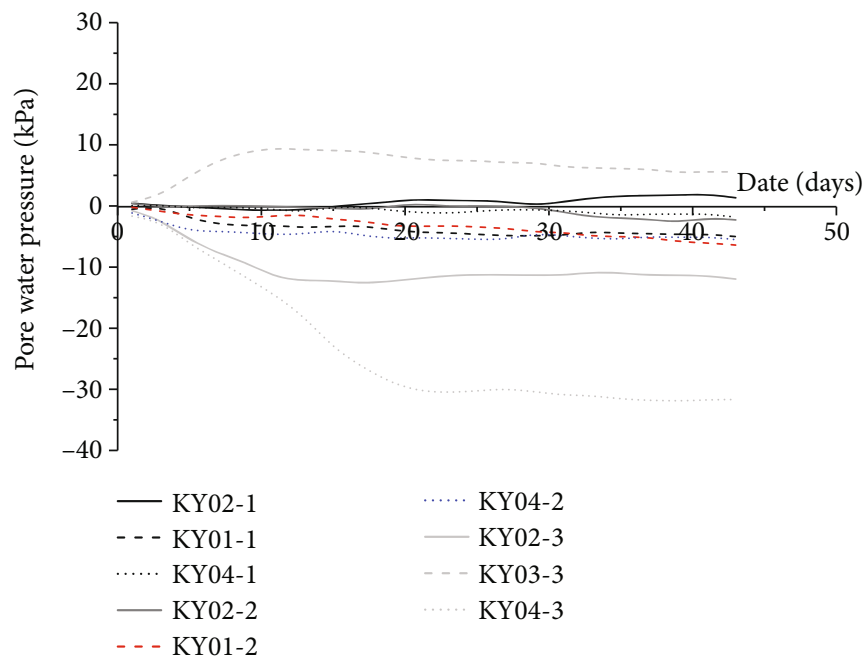

FIGURE 11: Time histories of pore water pressure at various monitoring points.

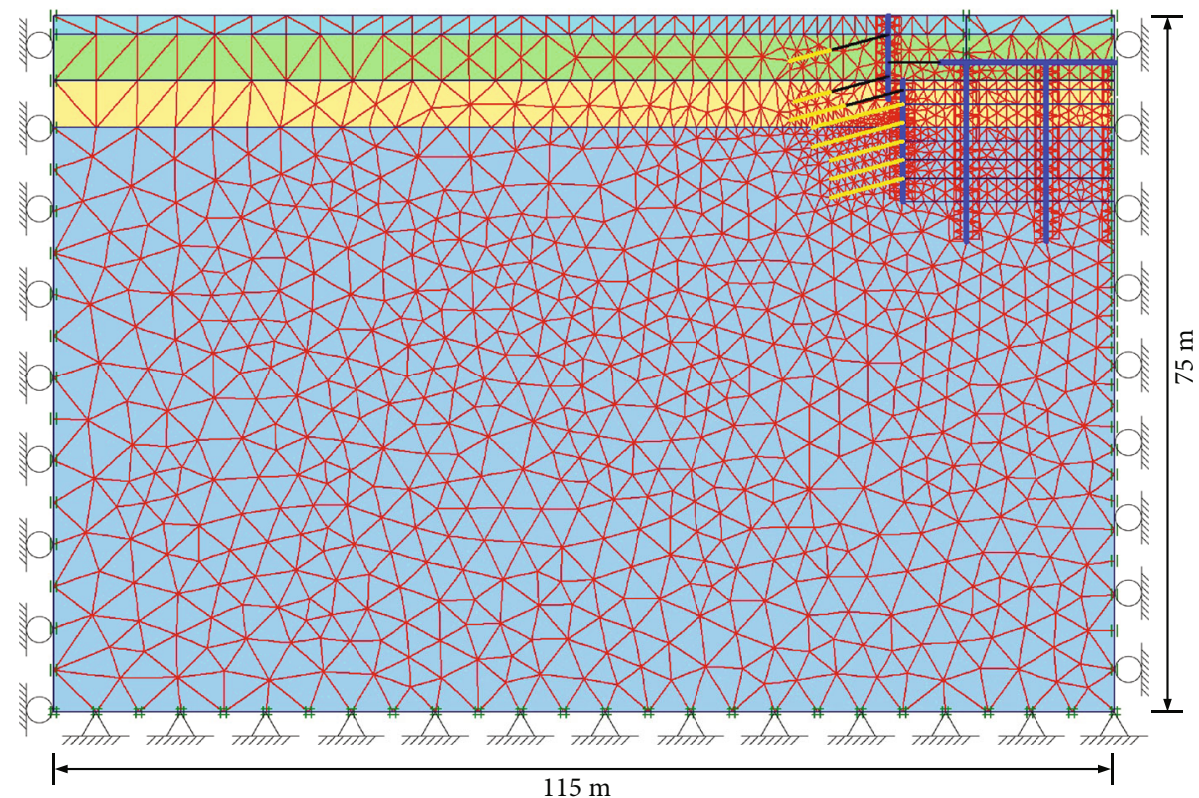

FIGURE 12: Meshing of the finite element analysis model.

3.6. Pore Water Pressure. Figure 11 shows the time histories of pore water pressure at various monitoring points. As is shown, the variational rate of the pore water pressure was slow at the selected monitoring points except the KY04-03. At KY04-03, the pore water pressure initially decreased at a relatively high velocity until the $20^{\text {th }}$ construction day, after which the decreasing velocity was reduced greatly. According to the principle of effective stress, the relationship among total stress $\sigma$, effective stress $\sigma^{\prime}$, and pore water pressure $\mu$ can be described by $\sigma=\sigma^{\prime}+\mu$. When the total stress $\sigma$ is kept constant, a negative correlation exists between effective stress $\sigma^{\prime}$ and pore water pressure $\mu$. During the station excavation, the unloading effect will lead to a reduction in the pore water pressure within the ground. Simultaneously, the effective stress increases, which will compress the soil, resulting in a repeated increase of the pore water pressure at some monitoring points.

\section{Finite Element Analysis}

4.1. Meshing and Boundary Conditions. The symmetry of the considered deep excavation case history was considered in the finite element analysis. Figure 12 shows the meshing of the finite element analysis model. As the length of the excavation in the longitudinal direction is much larger than that in the transverse direction, a 2D plane strain finite element model was established. According to the previous engineering experience and related numerical analysis results, the primary zone of excavation influence is characterized by a width of 2 to 4 times the final excavation depth and by a depth of 2 
TABLE 2: Soil parameters adopted in finite element analysis.

\begin{tabular}{lcccc}
\hline Parameter & Miscellaneous fill & Heavily weathered granite & Moderately weathered granite & Moderately weathered granite \\
\hline$\gamma_{\text {unsat }}\left(\mathrm{kN} / \mathrm{m}^{3}\right)$ & 17.5 & 23.5 & 24.5 & 25 \\
$\gamma_{\text {sat }}\left(\mathrm{kN} / \mathrm{m}^{3}\right)$ & 20 & 24.5 & 25 & 25.3 \\
$E(\mathrm{MPa})$ & 8 & 45 & 120 & 12000 \\
$E_{\text {inc }}(\mathrm{MPa} / \mathrm{m})$ & 0 & 0 & 0 & 500 \\
$v$ & 0.42 & 0.28 & 0.25 & 0.22 \\
$c(\mathrm{kPa})$ & 10 & 40 & 100 & 1800 \\
$\varphi\left({ }^{\circ}\right)$ & 8 & 25 & 35 & 45 \\
$\psi\left({ }^{\circ}\right)$ & 0 & 0 & 5 & 13 \\
$R_{\text {int }}$ & 0.67 & 0.8 & 1 & 1 \\
\hline
\end{tabular}

Note: $\gamma_{\text {unsat }}:$ natural unit weight; $\gamma_{\text {sat }}$ : saturated unit weight; $E$ : modulus of elasticity; $E_{\text {inc }}$ : incremental stiffness; $v$ : Poisson's ratio; $c$ : cohesion; $\varphi$ : angle of internal friction; $\psi$ : dilatancy angle; and $R_{\text {int }}:$ reduction factor for soil/structure interfacial shear strength.

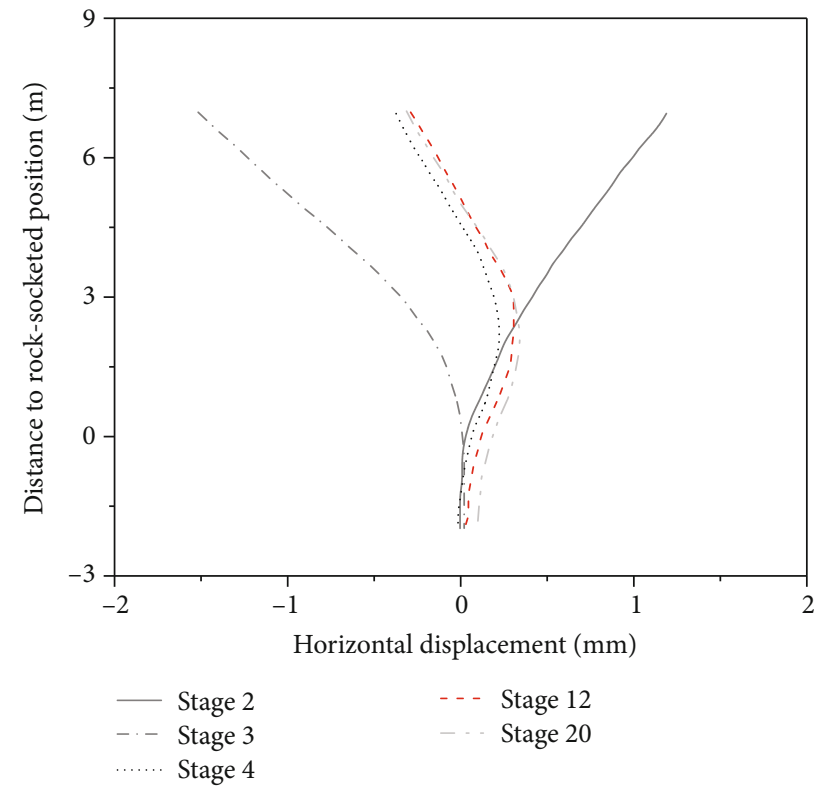

FIGURE 13: Variation of horizontal displacement of end-suspended pile with construction stage.

to 3 times the final excavation depth. Therefore, the dimensions of the established finite element analysis model were of $115 \mathrm{~m}$ in horizontal direction and $75 \mathrm{~m}$ in vertical direction. Roller supports were applied to the vertical boundaries to restrain the horizontal displacements, while pin supports were applied to the bottom of the mesh to restrict the displacements in all directions.

4.2. Constitutive Models and Parameters. In the numerical analysis, the Mohr-Coulomb model was used to describe the stress-strain behavior of the soils. Table 2 summarizes the soil parameters for the finite element analysis. The parameter, incremental stiffness $E_{\text {inc }}$, is a special option in PLAXIS [52] for the Mohr-Coulomb model. It is activated for inputting the soil stiffness as a function of cover depth, which is beneficial for revising the exaggerated basal heave involved in the application of this soil constitutive model. Considering the fact that the stiffness of the bracing structure

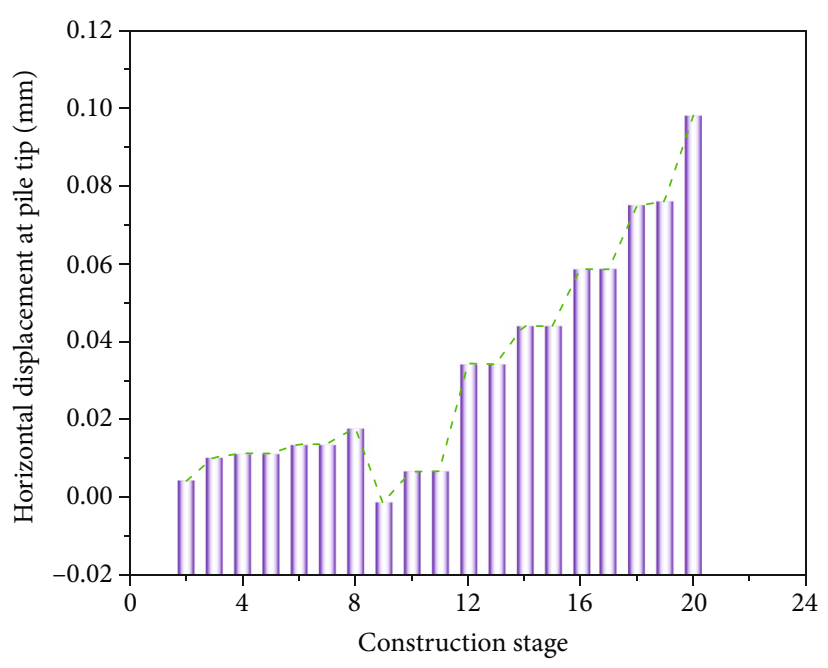

FIgURE 14: Variation of horizontal displacement at the endsuspended pile tip with a construction stage.

and the station structure is much larger than that of the soils, the linear elastic model was adopted to simulate the constitutive behavior of the structures.

The beam element was used to represent the endsuspended piles and steel pipe columns. In the numerical analysis, the real piles and columns of circular cross-section were transformed to beams of a rectangular cross-section. This transformation is based on the principle of equivalent flexural rigidity which has the form of

$$
\frac{\pi D^{4}}{64}=\frac{S d_{\mathrm{eq}}^{3}}{12}
$$

where $D$ is the diameter of pile or column, $S$ is the spacing between two piles or columns, and $d_{\text {eq }}$ is the equivalent thickness of the transformed beams.

A manipulation of Equation (2) yields

$$
d_{\mathrm{eq}}=\sqrt[3]{\frac{3 \pi D^{4}}{16 S}} .
$$




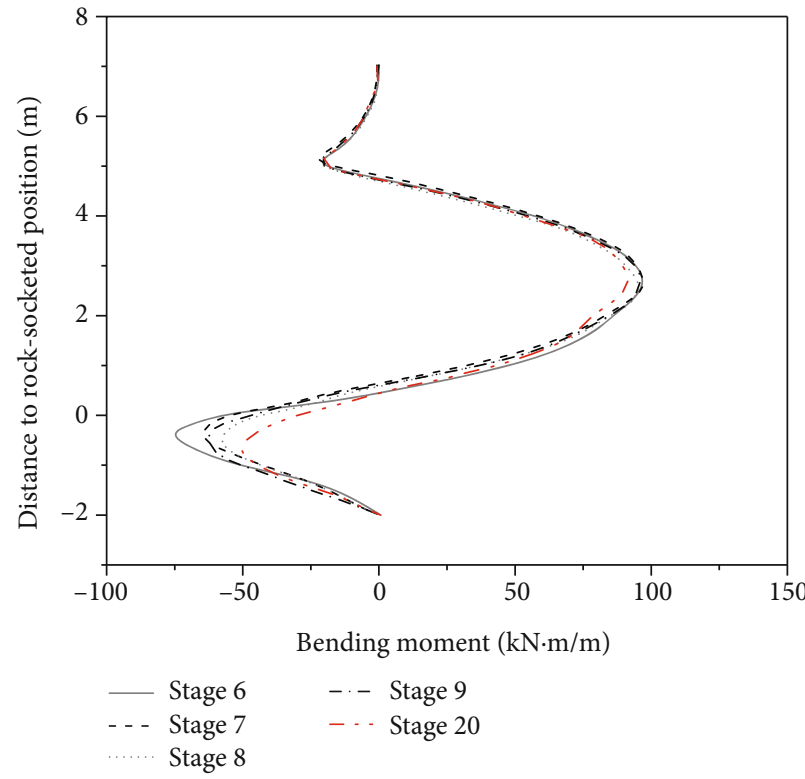

(a)

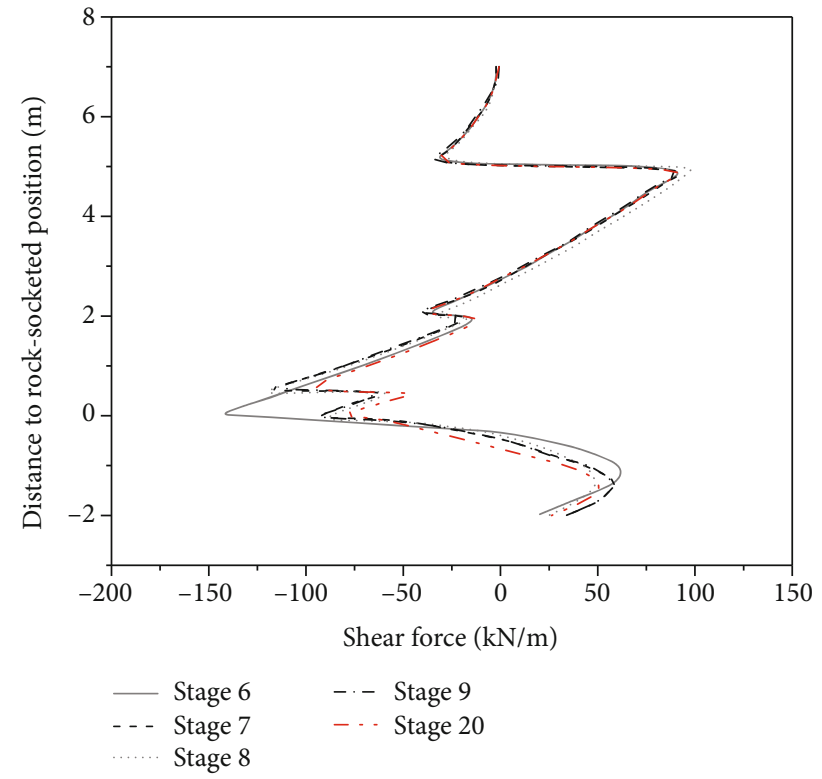

(b)

Figure 15: Variation of internal forces in the end-suspended pile with the construction stage. (a) Bending moment. (b) Shear force.

By using Equation (2), the equivalent thicknesses for the end-suspended piles, slabs, and steel pipe columns were derived which are, respectively, $0.73,1$, and $0.42 \mathrm{~m}$.

The anchorage sections of the prestressed ground anchors as well as the ground anchors in the granite layers were simulated using the geogrid element. For the geogrid element, the modulus of elasticity $E_{c}$ was calculated by

$$
E_{c}=\frac{A E_{s}+A_{m} E_{m}}{A+A_{m}},
$$

where $A$ is the cross-sectional area of the cable or bolt, $A_{m}$ is the cross-section area of grout, $E_{s}$ is the modulus of elasticity for the cable or bolt, and $E_{m}$ is the modulus of elasticity for the grout.

4.3. Deformation and Internal Force Characteristics of EndSuspended Piles. Figure 13 presents the variation of the horizontal displacement of the end-suspended pile with a construction stage. It can be indicated that at the excavation depth of $2 \mathrm{~m}$, the deformation of the pile was characterized by cantilever type. In other words, the horizontal pile displacement peaked at the pile top, while it was almost zero below the rock-socketed position. An observable increase in the horizontal pile displacement below the rock-socketed position occurred when the excavation depth reached $5 \mathrm{~m}$. At the excavation depth of $20 \mathrm{~m}$, the maximum horizontal pile displacement of $0.33 \mathrm{~mm}$ appeared at $2.25 \mathrm{~m}$ above the rock-socketed position. As a whole, because of the effect of the prestressed ground anchor attached to the pile top, the maximum horizontal displacement of the end-suspended pile, which occurred at the pile top, was achieved at the construction stage 2.

The variation of the horizontal displacement at endsuspended pile tip with construction stage is shown in
Figure 14. It can be noted that the horizontal pile tip displacement increased with an increase in the excavation depth. During the installation of the ground anchor YMG4, a significant change of the horizontal pile tip displacement occurred, indicating that the feet-lock prestressed ground anchor played an important role in controlling the horizontal pile tip displacement. A dramatic increase in the horizontal pile tip displacement was also observed when the rock within the range of pile embedment depth was excavated. This demonstrated that the restraining effect of the rock beneath the pile tip on the pile tip was noteworthy, although the embedment depth of the pile into the MWG layer was only $2 \mathrm{~m}$. Moreover, it can also be indicated from Figure 14 that a significant reduction in the horizontal displacement at the pile tip occurred between construction stages 8 and 12. This may be attributed to the application of a relatively large prestress of $310 \mathrm{kN}$ to the ground anchors of YMG4.

Figure 15 shows the variations of the bending moment and shear force in the end-suspended pile with the construction stage. It is shown that the effect of proceeding the construction stage on the internal forces within the upper $3 \mathrm{~m}$ of the pile was negligible. This was because the first level of the ground anchor attached to the pile top had restrained the horizontal pile displacement. As the maximum bending moment in the pile occurred between the first-level ground anchor and the temporary support, the prestress in the lower levels of ground anchors had a negligible effect on the maximum bending moment. Moreover, with a further increase in the excavation depth, the position at which the maximum negative bending moment occurred moved down gradually. When reaching the final excavation depth, the maximum negative bending moment appeared at $0.75 \mathrm{~m}$ below the rock-socketed position. Additionally, the shear force in the rock-socketed position decreased with increasing the excavation depth. 


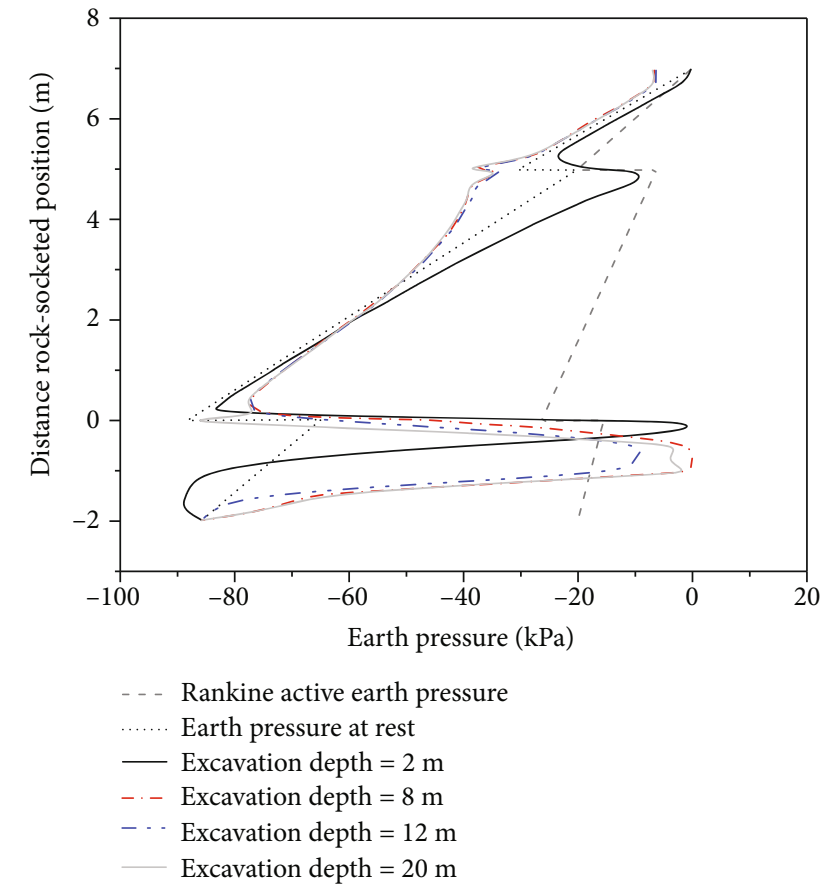

FIGURE 16: Earth pressure applied on the active side of the endsuspended pile at different excavation stages.

Figure 16 shows the variations of the earth pressure applied on the active side of the end-suspended pile with the distance to the rock-socketed position. It can be indicated that at the excavation depth of $2 \mathrm{~m}$, the soil behind the pile above the excavation face did not reach the active limit state due to the small magnitude of the horizontal pile displacement. Below the excavation face, with an increase in the cover depth, the horizontal pile displacement decreased gradually; and therefore, the active earth pressure applied on the pile gradually approached the earth pressure at rest. At the rock-socketed position (i.e., interface between soil and rock), the earth pressure equaled to nearly zero. This could be attributed to the fractures generated in the rock due to the detaching of the pile from the rock. Overall, both the distribution pattern and the magnitude of the earth pressure applied on the pile by the finite element analysis method agreed well with the results of the Rankine earth pressure theory. The discrepancy between them was distinct only at the interface of the soil and rock.

Figure 17 shows the variations of the earth pressure applied on the passive side of the end-suspended pile with the distance to rock-socketed position. The figure indicates that both the distribution pattern and the magnitude of the earth pressure obtained by the finite element method differed greatly from that predicted by the Rankine passive earth pressure theory. Therefore, it can be inferred that the limit equilibrium method may be not applicable for the design of the end-suspended pile. Therefore, it is recommended that the soil springs be adopted to simulate the passive earth pressure applied on the end-suspended pile. Moreover, it can be also indicated that the earth pressure distribution curves were

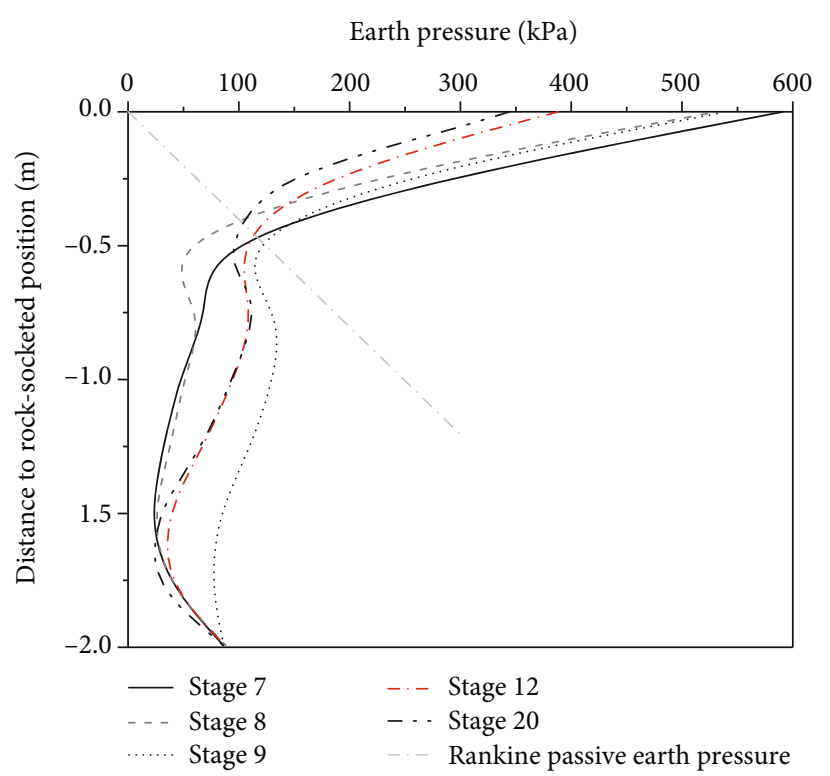

FIGURE 17: Earth pressure applied on the passive side of the endsuspended pile at different excavation stages.

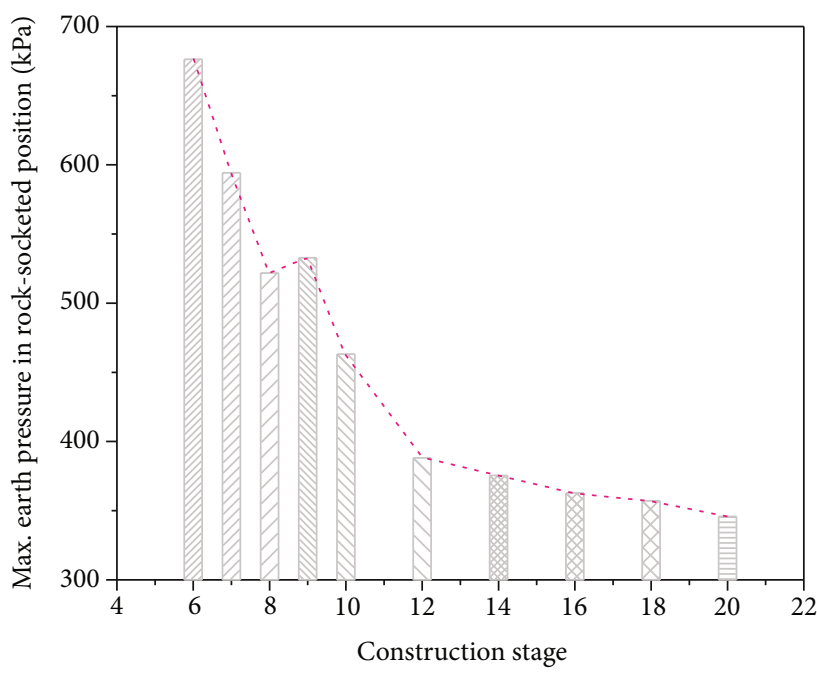

FIGURE 18: Variation of maximum earth pressure in the rocksocketed position with the construction stage.

similar before and after the excavation of the bedrock, and they peaked at the bedrock surface.

The variation of the maximum earth pressure in the rocksocketed position with excavation depth is presented in Figure 18. From the variational curve, it can be indicated that the maximum earth pressure decreased almost linearly with an increase in the excavation depth until reaching construction stage 8 . After completing the excavation of the slightly weathered granite, the rate of the decreasing trend for the maximum earth pressure became lower. This was partially attributed to the installation of the ground anchor YMG4. However, the installation of the ground anchor YMG4 did not compensate fully for the loss of the passive earth pressure induced by the excavation of the rock shoulder. 


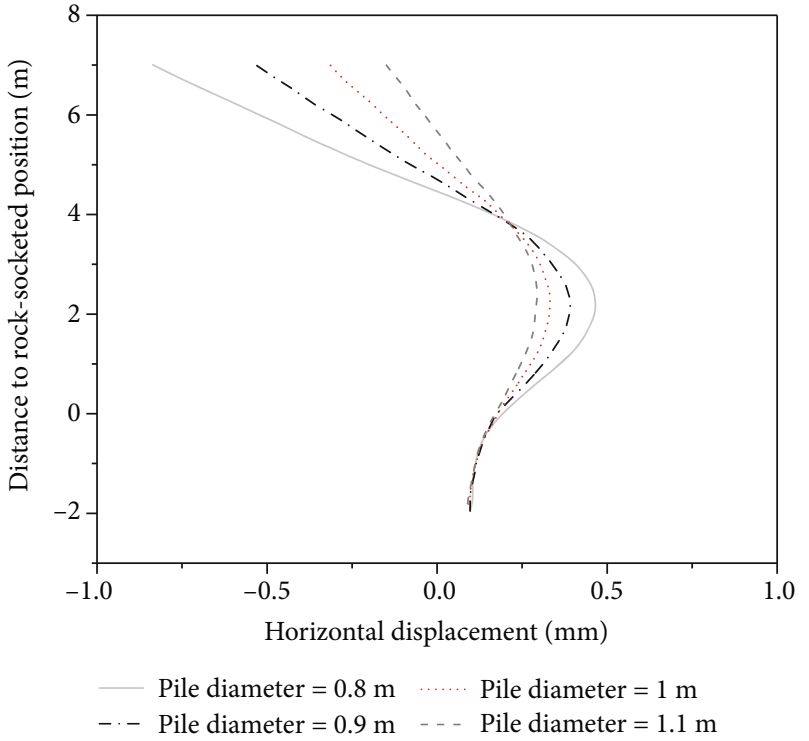

(a)



(b)

FIGURE 19: Effects of pile diameter on the horizontal displacement and bending moment of end-suspended pile. (a) Horizontal displacement. (b) Bending moment.

\section{Discussion}

5.1. Effects of Pile Diameter. Figure 19 shows the effects of pile diameter on the horizontal displacement and bending moment of the end-suspended pile. It can be indicated that for most parts of the pile shaft, the horizontal displacements decrease with an increase in pile diameter from 0.8 to $1.1 \mathrm{~m}$. However, the effects of the pile diameter on horizontal displacements are trivial at a distance to rock-socketed position of approximately $4 \mathrm{~m}$ or being less than $0 \mathrm{~m}$. From Figure 19(b), it is noted that the primary area of the effects of the pile diameter on the bending moment ranges between 1 and $4 \mathrm{~m}$ of the distance to the rock-socketed position. Moreover, within the primary area, the bending moment increases with increasing pile diameter; and the rate of increase in the bending moment decreases with increasing pile diameter.

The variational percentages of the maximum positive horizontal displacement and maximum bending moment of end-suspended pile at the considered magnitudes of pile diameter are presented in Figure 20. Note that the variational percentages are calculated based on the results at the pile diameter of $0.8 \mathrm{~m}$. It is shown that the decreasing trend of the maximum positive horizontal displacement with increasing pile diameter gradually becomes mitigatory. A reduction of approximately $30 \%$ in the maximum positive horizontal displacement appears when the pile diameter increases from 0.8 to $1 \mathrm{~m}$. This demonstrates the benefit of controlling excavation deformation by increasing the pile diameter. However, it is inevitable that work amount will be greatly increased with increasing pile diameter. In addition, Figure 20 also shows that with an increase in the pile diameter, the maximum bending moment increases accordingly. An increase of approximately $20 \%$ in the maximum bending moment occurs when the pile diameter increases from 0.8 to $1 \mathrm{~m}$.

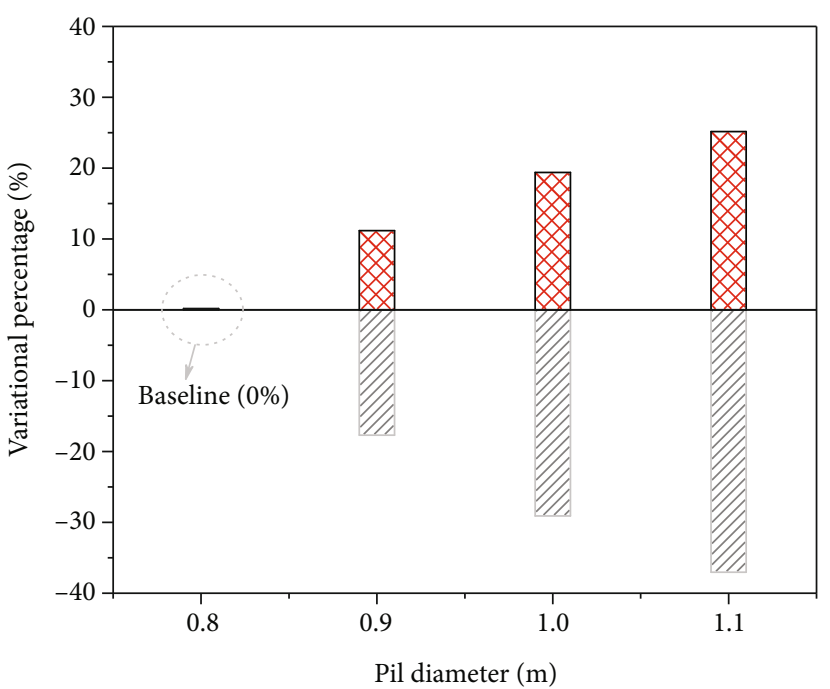

VII Maximum positive horizontal displacement Maximum bending moment

FIgURE 20: Variations of the maximum positive horizontal displacement and maximum bending moment of the endsuspended pile at different pile diameters.

5.2. Effects of Embedded Depth. Figure 21 presents the effects of embedded depth on the horizontal displacement and bending moment of the end-suspended pile. The variational percentages of the maximum positive horizontal displacement and the maximum bending moment at various magnitudes of embedded depth are shown in Figure 22. It is indicated that for the considered magnitudes of embedded depth, all the maximum horizontal displacements uniformly occur at a distance to rock-socketed position of $2.25 \mathrm{~m}$, which is located between the first row of ground anchors and the 


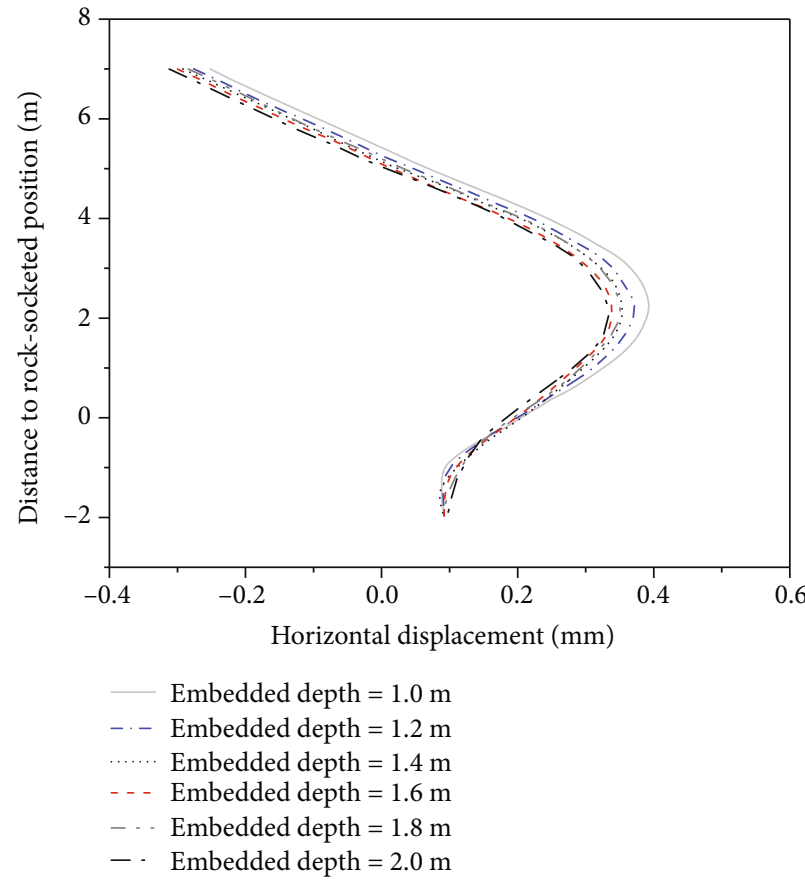

(a)

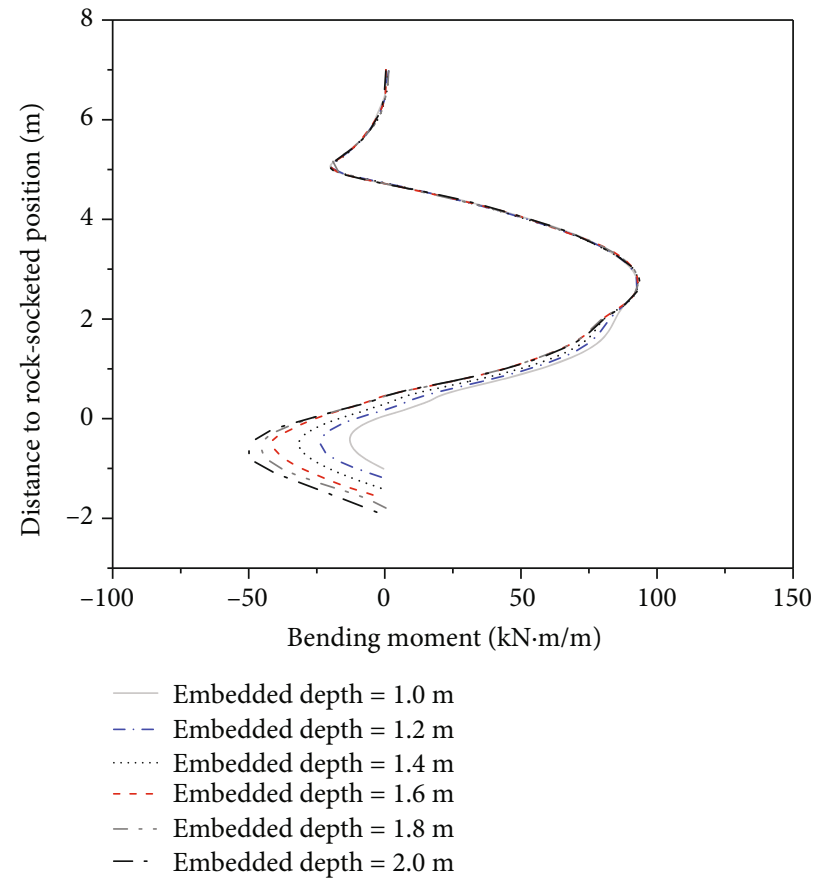

(b)

Figure 21: Effects of embedded depth on the horizontal displacement and bending moment of the end-suspended pile. (a) Horizontal displacement. (b) Bending moment.

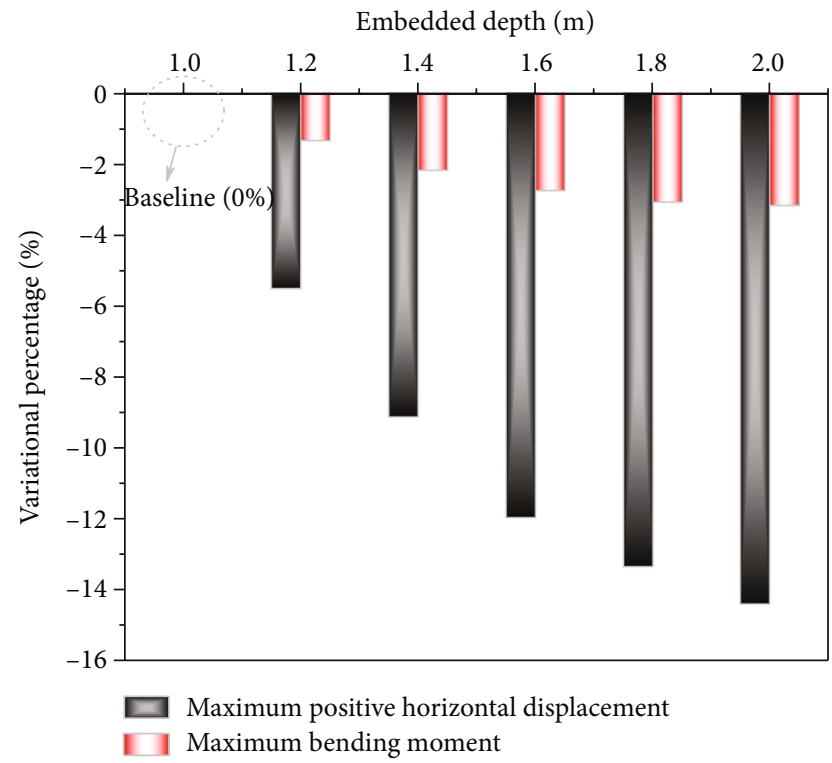

FIGURE 22: Variations of the maximum positive horizontal displacement and maximum bending moment of the endsuspended pile at different embedded depths.

temporary support. With an increase in the embedded depth, the horizontal displacement for the upper part of the endsuspended pile decreases at a relatively low rate. From Figure 22, it can be indicated that when the embedded depth increases from 1 to $2 \mathrm{~m}$, the maximum positive horizontal displacement of the end-suspended pile decreases by $14 \%$.
The position at which the maximum bending moment occurs is also located between the first row of ground anchors and the temporary support. An increase in the embedded depth affects only the bending moment for the part of pile shaft below the temporary support. Therefore, the effects of embedded depth on the maximum bending moment are very inappreciable. This phenomenon can be also observed in Figure 22 which shows a reduction in the maximum bending moment of merely $3.2 \%$ when the embedded depth increases from 1 to $2 \mathrm{~m}$.

5.3. Effects of Rock-Shoulder Width. Figure 23 shows the effects of rock-shoulder width on the horizontal displacement and bending moment of the end-suspended pile. It can be indicated that the occurrence position of the maximum horizontal displacement gradually moves upward with an increase in the rock-shoulder width. After reaching the rock-shoulder width of $1.1 \mathrm{~m}$, the occurrence position of the maximum horizontal displacement remains unchanged. This demonstrates that the rock-shoulder with a width of $1.1 \mathrm{~m}$ can provide sufficient earth resistance for restraining the tip of the end-suspended pile. An increase in the rockshoulder width has a relatively big effect on the horizontal displacement of the pile shaft below the temporary support. However, the horizontal displacement of the pile shaft above the temporary support remains nearly unchanged as the rock-shoulder width increases. Figure 24 shows the variational percentages of the maximum positive horizontal displacement and the maximum bending moment of the end-suspended pile at various magnitudes of rock-shoulder 


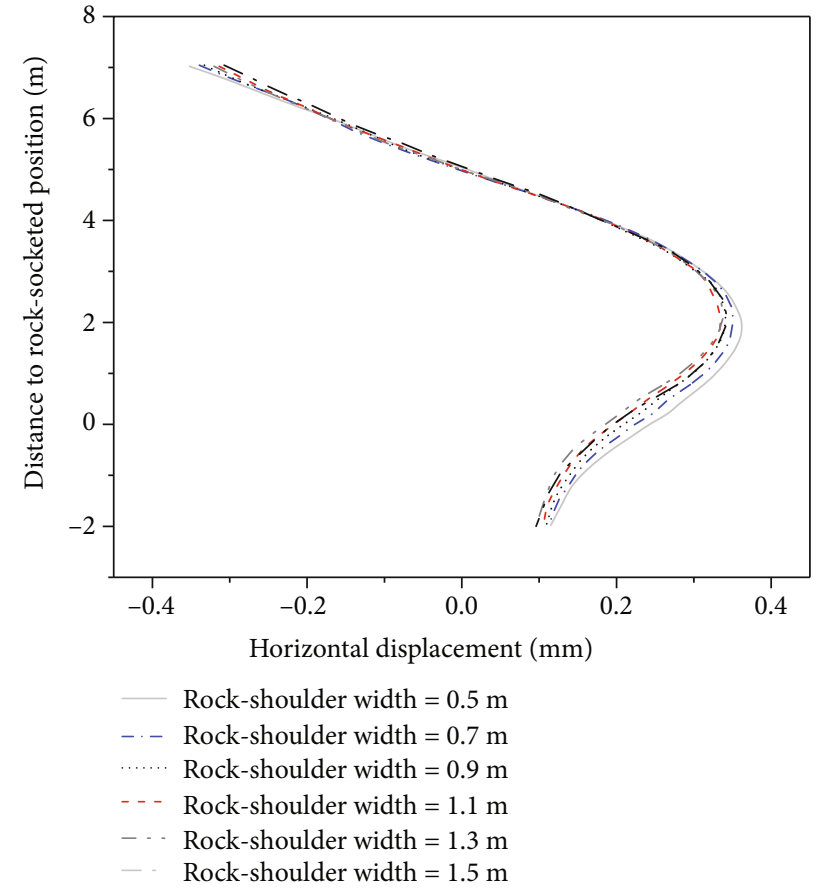

(a)



(b)

Figure 23: Effects of rock-shoulder width on the horizontal displacement and bending moment of the end-suspended pile. (a) Horizontal displacement. (b) Bending moment.

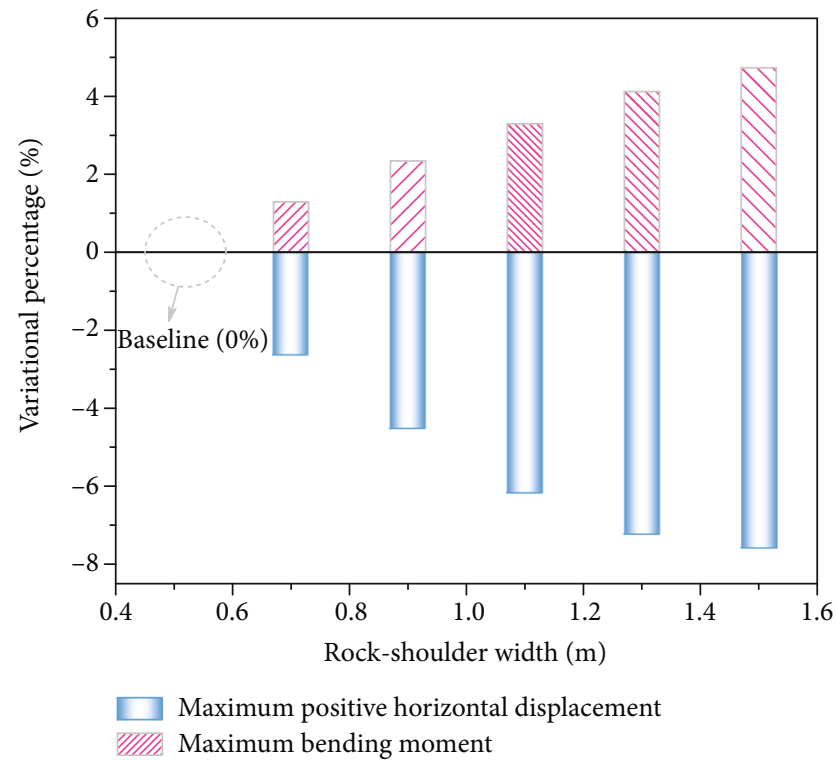

FIgURE 24: Variations of the maximum positive horizontal displacement and maximum bending moment of the endsuspended pile at different rock-shoulder widths.

width. It can be noted that a reduction of merely $6 \%$ in the maximum positive horizontal displacement occurs when the rock-shoulder width increases from 0.5 to $1.1 \mathrm{~m}$. Moreover, when the rock-shoulder width increases from 0.5 to $1.5 \mathrm{~m}$, an increase of approximately $4.7 \%$ in the maximum bending moment can be achieved.

\section{Conclusions}

The performance of top-down deep excavation braced with ground anchors and end-suspended piles in a soil-rock composite stratum was investigated by analysing the observed data for a typical case history in Tsingtao, China, and performing a series of finite element simulations. A parametric analysis based on finite element simulations was also made to capture the effects of pile diameter, embedded depth, and rock-shoulder width on the horizontal displacement and bending moment of the end-suspended pile. The conclusions drawn from this study can be summarized as follows.

(i) The deformation of end-suspended pile during excavation is of cantilever type. Due to the limited socketed force provided by the reserved rockshoulder with a relatively small width, the horizontal pile displacement is considerable at the rocksocketed position. The position at which the maximum bending moment in pile occurs gradually moves downward as proceeding the construction stages. With an increase in the excavation depth, the horizontal displacements for the socketed section of the end-suspended pile increase accordingly

(ii) Magnitudes of pile top settlements, ground surface settlements, and building settlements induced by top-down deep excavation braced with ground anchors and end-suspended piles are generally less than $20 \mathrm{~mm}$, indicating that the top-down excavation method has a beneficial effect on restraining 
the excavation-induced settlements in a soil-rock composite stratum

(iii) Within the primary influence zone of pile diameter ranging between 1 and $4 \mathrm{~m}$ of the distance to the rock-socketed position, the bending moment increases while the rate of increase in the bending moment decreases with increasing pile diameter. An increase in the embedded depth affects only the bending moment for the part of pile shaft below the temporary support. The horizontal displacement of the pile shaft above the temporary support remains nearly unchanged as the rock-shoulder width increases

(iv) A combination of the top-down method with a bracing system consisting of ground anchors and end-suspended piles is recommended for deep excavations in a soil-rock composite stratum, as it can effectively restrain the deformation of the excavation. Moreover, by implementing this combination, the construction costs can be significantly lowered due to the reduced rock-socketed depth of the piles as well as to the reduced difficulty of construction, when compared to the conventional excavation bracing system

\section{Data Availability}

The data used to support the findings of this study are available from the corresponding author upon request.

\section{Conflicts of Interest}

The authors declare that there are no conflicts of interest regarding the publication of this paper.

\section{Acknowledgments}

This study was supported by the Fundamental Research Funds for the Central Universities (201962011), the Laboratory for Marine Geology, Qingdao National Laboratory for Marine Science and Technology (MGQNLM-KF201804), and the National Natural Science Foundation of China (no. 41672272).

\section{References}

[1] C. Yuan, Z. Hu, Z. Zhu et al., "Numerical simulation of seepage and deformation in excavation of a deep foundation pit under water-rich fractured intrusive rock," Geofluids, vol. 2021, Article ID 6628882, 10 pages, 2021.

[2] E. Pujades, E. Vàzquez-Suñé, J. Carrera, and A. Jurado, "Dewatering of a deep excavation undertaken in a layered soil," Engineering Geology, vol. 178, pp. 15-27, 2014.

[3] Q. Zhang, B. Huang, M. He, and S. Guo, "A numerical investigation on the hydraulic fracturing effect of water inrush during tunnel excavation," Geofluids, vol. 2020, Article ID 6196327, 15 pages, 2020.
[4] P. Guo, F. Liu, G. Lei et al., "Predicting response of constructed tunnel to adjacent excavation with dewatering," Geofluids, vol. 2021, Article ID 5548817, 17 pages, 2021.

[5] R. Zhang, J. Zheng, H. Pu, and L. Zhang, "Analysis of excavation-induced responses of loaded pile foundations considering unloading effect," Tunnelling and Underground Space Technology, vol. 26, no. 2, pp. 320-335, 2011.

[6] C. W. W. Ng, M. Shakeel, J. Wei, and S. Lin, "Performance of existing piled raft and pile group due to adjacent multipropped excavation: 3D centrifuge and numerical modeling," Journal of Geotechnical and Geoenvironmental Engineering, vol. 147, no. 4, 2021.

[7] R.-f. Feng, Q.-q. Zhang, and S.-w. Liu, "Experimental study of the effect of excavation on existing loaded piles," Journal of Geotechnical and Geoenvironmental Engineering, vol. 146, no. 9, 2020.

[8] Y. Tan, R. Huang, Z. Kang, and W. Bin, "Covered semi-topdown excavation of subway station surrounded by closely spaced buildings in downtown Shanghai: building response," Journal of Performance of Constructed Facilities, vol. 30, no. 6, 2016.

[9] P. Guo, X. Gong, and Y. Wang, "Displacement and force analyses of braced structure of deep excavation considering unsymmetrical surcharge effect," Computers and Geotechnics, vol. 113, 2019.

[10] K. Cheng, R. Xu, H. Ying, X. Gan, L. Zhang, and S. Liu, "Observed performance of a $30.2 \mathrm{~m}$ deep-large basement excavation in Hangzhou soft clay," Tunnelling and Underground Space Technology, vol. 111, 2021.

[11] Y. M. Hou, J. H. Wang, and L. L. Zhang, "Finite-element modeling of a complex deep excavation in Shanghai," Acta Geotechnica, vol. 4, no. 1, pp. 7-16, 2009.

[12] C. W. W. Ng, Y. Hong, G. B. Liu, and T. Liu, "Ground deformations and soil-structure interaction of a multi-propped excavation in Shanghai soft clays," Géotechnique, vol. 62, no. 10, pp. 907-921, 2012.

[13] Y. M. A. Hashash and A. J. Whittle, "Ground movement prediction for deep excavations in soft clay," Journal of Geotechnical Engineering, vol. 122, no. 6, pp. 474-486, 1996.

[14] D. Wu, K. Xu, P. Guo, G. Lei, K. Cheng, and X. Gong, “Ground deformation characteristics induced by mechanized shield twin tunnelling along curved alignments," Advances in Civil Engineering, vol. 2021, Article ID 6640072, 17 pages, 2021.

[15] M. Son and E. J. Cording, "Numerical model tests of building response to excavation-induced ground movements," Canadian Geotechnical Journal, vol. 45, no. 11, pp. 1611-1621, 2008.

[16] G. B. Liu, P. Huang, J. W. Shi, and C. W. W. Ng, "Performance of a deep excavation and its effect on adjacent tunnels in shanghai soft clay," Journal of Performance of Constructed Facilities, vol. 30, no. 6, 2016.

[17] M. J. Schuster, C. H. Juang, M. J. S. Roth, and D. V. Rosowsky, "Reliability analysis of building serviceability problems caused by excavation," Géotechnique, vol. 58, no. 9, pp. 743-749, 2008.

[18] S. Burlon, H. Mroueh, and I. Shahrour, "Influence of diaphragm wall installation on the numerical analysis of deep excavation," International Journal for Numerical and Analytical Methods in Geomechanics, vol. 37, no. 11, pp. 1670-1684, 2013.

[19] S. Likitlersuang, C. Surarak, D. Wanatowski, E. Oh, and A. Balasubramaniam, "Finite element analysis of a deep 
excavation: a case study from the Bangkok MRT," Soils and Foundations, vol. 53, no. 5, pp. 756-773, 2013.

[20] Y. Tang, S. Xiao, and Y. Zhan, "Predicting settlement along railway due to excavation using empirical method and neural networks," Soils and Foundations, vol. 59, no. 4, pp. 10371051, 2019.

[21] W. Zhang, A. T. C. Goh, and F. Xuan, "A simple prediction model for wall deflection caused by braced excavation in clays," Computers and Geotechnics, vol. 63, pp. 67-72, 2015.

[22] M. Korff, R. J. Mair, and F. A. F. Van Tol, "Pile-soil interaction and settlement effects induced by deep excavations," Journal of Geotechnical and Geoenvironmental Engineering, vol. 142, no. 8, 2016.

[23] G. T. C. Kung, C. H. Juang, E. C. L. Hsiao, and Y. M. A. Hashash, "Simplified model for wall deflection and groundsurface settlement caused by braced excavation in clays," Journal of Geotechnical and Geoenvironmental Engineering, vol. 133, no. 6, pp. 731-747, 2007.

[24] L. Masini, D. Gaudio, S. Rampello, and E. Romani, “Observed performance of a deep excavation in the historical center of Rome," Journal of Geotechnical and Geoenvironmental Engineering, vol. 147, no. 2, 2021.

[25] F.-Y. Zeng, Z.-J. Zhang, J.-H. Wang, and M.-G. Li, “Observed performance of two adjacent and concurrently excavated deep foundation pits in soft clay," Journal of Performance of Constructed Facilities, vol. 32, no. 4, 2018.

[26] Q. Fu and L. Li, "Vertical load transfer behavior of composite foundation and its responses to adjacent excavation: centrifuge model test," Geotechnical Testing Journal, vol. 44, no. 1, 2021.

[27] X. S. Cheng, G. Zheng, Y. Diao et al., "Experimental study of the progressive collapse mechanism of excavations retained by cantilever piles," Canadian Geotechnical Journal, vol. 54, no. 4, pp. 574-587, 2017.

[28] S.-S. Lin, S.-L. Shen, A. Zhou, and Y.-S. Xu, "Risk assessment and management of excavation system based on fuzzy set theory and machine learning methods," Automation in Construction, vol. 122, 2021.

[29] Y. Pu, D. B. Apel, and R. Hall, "Using machine learning approach for microseismic events recognition in underground excavations: comparison of ten frequently-used models," Engineering Geology, vol. 268, 2020.

[30] M. N. Houhou, F. Emeriault, and A. Belounar, "Three-dimensional numerical back-analysis of a monitored deep excavation retained by strutted diaphragm walls," Tunnelling and Underground Space Technology, vol. 83, pp. 153-164, 2019.

[31] P.-G. Hsieh, C.-Y. Ou, and Y.-L. Lin, "Three-dimensional numerical analysis of deep excavations with cross walls," Acta Geotechnica, vol. 8, no. 1, pp. 33-48, 2013.

[32] G. Zheng, X. Yang, H. Zhou, Y. Du, J. Sun, and X. Yu, “A simplified prediction method for evaluating tunnel displacement induced by laterally adjacent excavations," Computers and Geotechnics, vol. 95, pp. 119-128, 2018.

[33] Y. Wang, X. Shang, and K. Peng, "Relocating mining microseismic earthquakes in a 3-D velocity model using a windowed cross-correlation technique," IEEE Access, vol. 8, pp. 3786637878, 2020.

[34] Y. Tan, B. Wei, Y. Diao, and X. Zhou, "Spatial corner effects of long and narrow multipropped deep excavations in Shanghai soft clay," Journal of Performance of Constructed Facilities, vol. 28 , no. $4,2014$.
[35] F.-H. Lee, K.-Y. Yong, K. C. N. Quan, and K.-T. Chee, "Effect of corners in strutted excavations: field monitoring and case histories," Journal of Geotechnical and Geoenvironmental Engineering, vol. 124, no. 4, pp. 339-349, 1998.

[36] C.-Y. Ou and B.-Y. Shiau, "Analysis of the corner effect on excavation behaviors," Canadian Geotechnical Journal, vol. 35, no. 3, pp. 532-540, 1998.

[37] J. H. Wang, Z. H. Xu, and W. D. Wang, "Wall and ground movements due to deep excavations in Shanghai soft soils," Journal of Geotechnical and Geoenvironmental Engineering, vol. 136, no. 7, pp. 985-994, 2010.

[38] G. Russo, M. V. Nicotera, and S. Autuori, "Three-dimensional performance of a deep excavation in sand," Journal of Geotechnical and Geoenvironmental Engineering, vol. 145, no. 4, 2019.

[39] Q.-L. Cui, H.-N. Wu, S.-L. Shen, and Y.-S. Xu, "Geological difficulties and countermeasures for socket diaphragm walls in weathered granite in Shenzhen, China," Bulletin of Engineering Geology and the Environment, vol. 75, no. 1, pp. 263-273, 2016.

[40] K. Elbaz, S.-L. Shen, Y. Tan, and W.-C. Cheng, "Investigation into performance of deep excavation in sand covered karst: a case report," Soils and Foundations, vol. 58, no. 4, pp. 1042 1058, 2018.

[41] Y. Mei, Y.-L. Li, X.-Y. Wang, J. Wang, and C.-M. Hu, "Statistical analysis of deformation laws of deep foundation pits in collapsible loess," Arabian Journal for Science and Engineering, vol. 44, no. 10, pp. 8347-8360, 2019.

[42] H. Chen, J. Li, and L. Li, "Performance of a zoned excavation by bottom-up technique in Shanghai soft soils," Journal of Geotechnical and Geoenvironmental Engineering, vol. 144, no. 11, 2018.

[43] M. Khoiri and C.-Y. Ou, "Evaluation of deformation parameter for deep excavation in sand through case histories," Computers and Geotechnics, vol. 47, pp. 57-67, 2013.

[44] M.-G. Li, J.-J. Chen, A.-J. Xu, X.-H. Xia, and J.-H. Wang, "Case study of innovative top-down construction method with channel-type excavation," Journal of Construction Engineering and Management, vol. 140, no. 5, 2014.

[45] Y. Ikuta, M. Maruoka, M. Aoki, and E. Sato, "Application of the observational method to a deep basement excavated using the top-down method," Géotechnique, vol. 44, no. 4, pp. 655679, 1994.

[46] P. Jamsawang, P. Voottipruex, P. Tanseng, P. Jongpradist, and D. T. Bergado, "Effectiveness of deep cement mixing walls with top-down construction for deep excavations in soft clay: case study and 3D simulation," Acta Geotechnica, vol. 14, no. 1, pp. 225-246, 2019.

[47] Y. Tan, H. Zhu, F. Peng, K. Karlsrud, and B. Wei, "Characterization of semi-top-down excavation for subway station in Shanghai soft ground," Tunnelling and Underground Space Technology, vol. 68, pp. 244-261, 2017.

[48] M. Long, "Database for retaining wall and ground movements due to deep excavations," Journal of Geotechnical and Geoenvironmental Engineering, vol. 127, no. 3, pp. 203-224, 2001.

[49] C. Moormann, "Analysis of wall and ground movements due to deep excavations in soft soil based on a new worldwide database," Soils and Foundations, vol. 44, no. 1, pp. 87-98, 2004.

[50] M. W. Seo, S. M. Olson, K. S. Yang, and M. M. Kim, “Sequential analysis of ground movements at three deep excavation sites with mixed ground profiles," Journal of Geotechnical 
and Geoenvironmental Engineering, vol. 136, no. 5, pp. 656668, 2010.

[51] G. Lei and X. Gong, "Analysis of lateral displacement law of deep foundation pit support in soft soil based on improved MSD method," Advances in Civil Engineering, vol. 2021, Article ID 5550214, 15 pages, 2021.

[52] C. Chheng and S. Likitlersuang, "Underground excavation behaviour in Bangkok using three-dimensional finite element method," Computers and Geotechnics, vol. 95, pp. 68-81, 2018. 